\title{
PREVALENCE OF MALNUTRITION IN CHILDREN WITH CHRONIC HEPATITIS B INFECTION
}

\author{
Yasin ŞAHIN
}

Received 29/6/15 Accepted 15/1/2016

\begin{abstract}
Background - There have been limited studies investigating the impact of chronic hepatitis B virus infection on the growth of children. Objective - Our objective was to investigate the prevalence of malnutrition in children with chronic hepatitis B infection. Methods - The nutritional status of patients was retrospectively evaluated in the outpatient Clinic of Pediatric Gastroenterology between February and November 2014. During the study, biochemical laboratory parameters, duration of disease, liver biopsy scores, and medication were evaluated. Additionally body mass index and body mass index centiles were calculated. Results - Of the 96 patients in this study, 68 were male and 28 were female, and the mean age was $144.7 \pm 43.9$ months and $146.1 \pm 47.3$ months, respectively. According to body mass index centiles five (5.2\%) patients were underweight, seven $(7.3 \%)$ patients were overweight, and seven (7.3\%) patients were obese. Conclusions - Moderate rates of malnutrition (including obesity) were found in chronic hepatitis $\mathrm{B}$ infection. Additional nutritional status information of healthy and sick children should be assessed in the infection's early period, and timely interventions should be initiated.
\end{abstract}

HEADINGS - Child nutrition disorders. Chronic hepatitis B. Nutritional status.

\section{INTRODUCTION}

Chronic hepatitis B virus (HBV) infection is defined as the continuation of hepatitis B surface antigen positivity for at least 6 months. It is a mild illness, and usually asymptomatic in childhood ${ }^{(15)}$. HBV infection is still one of the most important causes of liver disease: 2 million people around the world become infected each year and more than 600,000 deaths occur ${ }^{(28)}$. The World Health Organization (WHO) has estimated that 360 million people are chronic carriers of $\mathrm{HBV}^{(28)}$.

Malnutrition is characterized by a deficient or excess intake of nutrients or by an imbalance of nutrients; these cause adverse effects on growth and development and may increase morbidity and mortality. Malnutrition also includes the term obesity ${ }^{(18)}$.

Malnutrition is reported to be directly or indirectly responsible for $50 \%-60 \%$ of the childhood mortality worldwide ${ }^{(22)}$. The prevalence of malnutrition in hospitalized children has not decreased over the past 20 years $^{(4)}$.

Children with chronic HBV infection mostly have normal growth and physical examination findings ${ }^{(15)}$. There have been limited studies investigating the impact of chronic HBV infection on the growth of children $^{(2,5,9,12,19,20,24,27)}$. Although severe malnutrition is easily diagnosed, the diagnoses of mild or moderate malnutrition often are overlooked when coping with a child's primary disease.
The aim of our study was to investigate the prevalence of malnutrition in children with chronic $\mathrm{HBV}$ infection.

\section{METHODS}

Children with chronic HBV infection followed in the outpatient Clinic of Pediatric Gastroenterology-Hepatology and Nutrition, Medical Faculty of Gaziantep University, between February and November 2014 were included in the study. They were evaluated from file records. Age, sex, height, weight, age at diagnosis, duration of disease, medication, protein, albumin, alanine aminotransferase (ALT), aspartate aminotransferase (AST), gamma-glutamyl transpeptidase (GGT), and histological activity index (HAI) were noted.

From height and weight values, body mass index, and body mass index centiles were used to assess patients' nutritional status. Sex-specific body mass index (BMI)-for-age growth charts were used to assess excess body weight, according to the World Health Organization criteria ${ }^{(11)}$.

The study was retrospective and based on file records; therefore, ethics committee approval was not required. This research was performed in accordance with the principles of the Helsinki Declaration as revised in 2008. 


\section{Statistical analysis}

The Mann-Whitney $\mathrm{U}$ test was used to compare groups of numerical variables, and the relationships between categorical variables were analyzed by chi-square test. Finally, a multivariate analysis was used to assess the influence of chronic hepatitis $\mathrm{b}$ infection on malnutrition. $P<0.05$ was considered statistically significant. The SPSS for Windows, version 22 , software package was used in the analysis.

\section{RESULTS}

Of the 96 patients in the study, $68(70.8 \%)$ were male and $28(29.2 \%)$ female, and the mean ages were $144.7 \pm 43.9$ months and $146.1 \pm 47.3$ months, respectively. Patients' demographic and anthropometric characteristics are shown in Table 1; malnutrition rates in regard to body mass index centiles are shown in Table 2; and laboratory findings and demographic parameters in patients with and without malnutrition are shown in Table 3 .

TABLE 1. Patients' demographic and anthropometric characteristics

\begin{tabular}{|c|c|}
\hline & Mean \pm SD $(\min -\max )$ \\
\hline Age (mo) & $145.1 \pm 44.7(30-214)$ \\
\hline Height $(\mathrm{cm})$ & $147.5 \pm 21.3(91-183)$ \\
\hline Weight (kg) & $43.0 \pm 16.9(12.7-77.3)$ \\
\hline Height for age (\%) & $98.7 \pm 4.5(86-108)$ \\
\hline Weight for age $(\%)$ & $100.5 \pm 19.8(66-169)$ \\
\hline Weight for height (\%) & $104.7 \pm 13.9(79-150)$ \\
\hline Weight for age $\mathrm{z}$ score & $-0.13 \pm 1.08(-3.6$ to 2.2$)$ \\
\hline Height for age $\mathrm{z}$ score & $-0.28 \pm 1.0(-3.0$ to 1.9$)$ \\
\hline BMI & $18.8 \pm 3.3(12.3-27.5)$ \\
\hline BMI centile & $50.2 \pm 29.1(0.1-97.9)$ \\
\hline ALT & $41.5 \pm 45.8(8-312)$ \\
\hline AST & $36.5 \pm 21.9(12-148)$ \\
\hline Protein & $7.3 \pm 0.5(6.3-8.4)$ \\
\hline Albumin & $4.6 \pm 0.2(4.0-5.3)$ \\
\hline GGT & $13.8 \pm 6.7(7-53)$ \\
\hline HAI & $5.4 \pm 1.8(2-9)$ \\
\hline Duration of disease (months) & $56.9 \pm 45.3(1-197)$ \\
\hline \multicolumn{2}{|c|}{$\begin{array}{l}\text { ALT: alanine aminotransferase; AST: aspartate aminotransferase; BMI: body mass index; GG } \\
\text { gamma-glutamyl transpeptidase, HAI: histological activity index; min-max: minimur } \\
\text {-maximum; SD: standard deviation. }\end{array}$} \\
\hline \multicolumn{2}{|c|}{ TABLE 2. Malnutrition rates in regard to BMI } \\
\hline Classification BMI centile & $\mathrm{n}(\%)$ \\
\hline$<5$ & $5(5.2)$ \\
\hline $5-85$ & $77(80.2)$ \\
\hline $85-95$ & $7(7.3)$ \\
\hline$>95$ & $7(7.3)$ \\
\hline
\end{tabular}

BMI: body mass index.
TABLE 3. Comparison of laboratory findings and demographic parameters in patients with and without malnutrition

\begin{tabular}{lccc}
\hline & $\begin{array}{c}\text { Malnourished } \\
(\mathbf{n}=5)\end{array}$ & $\begin{array}{c}\text { Not malnourished } \\
(\mathbf{n}=91)\end{array}$ & $\boldsymbol{P}$ \\
\hline Age $(\mathrm{mo})$ & $152.2 \pm 57.5$ & $144.7 \pm 44.2$ & 0.729 \\
$\begin{array}{l}\text { Duration of } \\
\text { disease }(\mathrm{mo})\end{array}$ & $49.6 \pm 40.4$ & $57.4 \pm 45.7$ & 0.798 \\
ALT & $40.0 \pm 10.4$ & $41.6 \pm 46.9$ & 0.102 \\
AST & $40.0 \pm 9.4$ & $36.3 \pm 22.4$ & 0.088 \\
Protein & $7.4 \pm 0.3$ & $7.3 \pm 0.5$ & 0.272 \\
Albumin & $4.6 \pm 0.1$ & $4.6 \pm 0.2$ & 0.405 \\
GGT & $20.9 \pm 18.5$ & $13.5 \pm 5.5$ & 0.036 \\
\hline
\end{tabular}

ALT: alanine aminotransferase; AST: aspartate aminotransferase; GGT: gamma-glutamyl transpeptidase.

Sexual maturation was determined based on the stages of development proposed by Tanner, comprising five stages for genital (G) (in males) and breast (B) (in females) development ${ }^{(21)}$. Chronological age was higher with advancing pubertal development in males, with mean and standard deviation for $\mathrm{G} 1$ of $77.6 \pm 28.3$ months $(\mathrm{n}=14)$; for $\mathrm{G} 2$, $132.9 \pm 15.3$ months $(n=11)$; for $G 3,157.9 \pm 24.4$ months $(n=24)$; for $G 4,185.2 \pm 13.3$ months $(n=17)$; and for $G 5$, $183.5 \pm 20.5$ months $(n=2)$. In females, chronological age was also higher with advancing pubertal development, with mean and standard deviation for B1 of $75.7 \pm 22.4$ months $(n=6)$; for B2, 109.0 \pm 7.9 months $(n=3)$; for B3, 140.7 \pm 18.6 months $(n=3)$; and for B4, $180.5 \pm 16.9$ months $(n=16)$. In the present study, sexual maturation was associated with significant differences in BMI centiles $(P<0.05)$. There was only five males in malnutrition group. Only, one of them has late sexual maturation.

In the present study, 50 patients with $\mathrm{HBV}$ were in the immune-tolerant phase, 36 were inactive carriers, and 10 were in the immune-active phase. According to the mode of transmission, 69 patients were vertically infected, 16 were parenterally infected, and 11 were infected by an unknown transmission. In multivariate analysis, there was no statistically significant difference between patients with and without malnutrition in regard to phases of chronic HBV $(P>0.05)$.

There was no statistically significant difference between patients with and without malnutrition in regard to the education level of parents $(P>0.05)$.

There was no statistically significant difference between patients with and without malnutrition in regard to ALT levels $(P>0.05)$, but $13(100.0 \%)$ patients with ALT levels $>1.5$ times' normal were in the group without malnutrition. Five of them $(38.5 \%)$ have received treatment. When evaluating the patients in terms of malnutrition, there was a significant difference only between GGT levels $(P<0.05)$. There was also no statistically significant difference between patients who were and were not obese in regard to age, duration of disease, biochemical laboratory parameters, histologic 
activity scores, medication, phases of chronic HBV, hepatitis B viral load $(P>0.05)$.

A liver biopsy was performed in 32 patients; medication was administered to 26 . Treatment was administered to six patients without liver biopsy at other centers. The HAI scores of two patients could not be acquired because the liver biopsies had been performed in another center. In the current study, 32 $(33.3 \%)$ patients had either received treatment or completed treatment during the study. The mean HAI score was 5.4 \pm 1.8 .

Based on BMI centiles, five $(5.2 \%)$ patients were underweight, seven (7.3) were overweight, and seven $(7.3 \%)$ were obese. When evaluating the groups in regard to the multivariate analysis, there was no statistically significant difference between patients with and without malnutrition $(P>0.05)$.

\section{DISCUSSION}

HBV is found in percutaneous and mucous membranes and is transmitted through infected blood, semen, vaginal secretions, and saliva ${ }^{(17)}$. Horizontal transmission is responsible for $37 \%-52 \%$ of all chronic HBV infections. Many children become infected through maternal vertical transmission during the perinatal period, which accounts for $13 \%-26 \%$ of HBV transmission globally ${ }^{(13)}$. In the present study, the rates of perinatal transmission, horizontal transmission, and unknown etiology were $71.9 \%, 16.7 \%$, and $11.4 \%$, respectively. The higher rate of perinatal transmission may be attributed to the present study being cross-sectional; in addition, the majority of our patients are the babies of hepatitis B e antigen-positive mothers with high viremia rates ${ }^{(6)}$.

The mechanisms that affect growth in chronic diseases are multiple and complex. For example, reduced calorie intake, nutrient malabsorption, the effects of chronic liver disease, or inflammatory mediators of insulin-like growth factor production in the liver can have a negative effect on growth in children with $\mathrm{HBV}$ infection ${ }^{(3,12)}$. Catabolism during infection is an important mechanism causing growth retardation ${ }^{(3)}$. The liver has an important role in regulating metabolism, maintaining homeostasis, and absorbing nutrients. Chronic liver disease causes malnutrition, leading to impaired daily calorie intake and anorexia ${ }^{(23)}$. Anorexia is one of the clinical features of chronic HBV infection ${ }^{(10)}$. HBV seroprevalence is higher in rural areas and in low socioeconomic level groups $^{(16,25)}$; therefore, a dual diagnosis of HBV infection and malnutrition is expected. In contrast, growth retardation has rarely been reported in chronic HBV infection ${ }^{(5)}$. One study reported on a group of children with chronic hepatitis $\mathrm{B}$; although there was no weight loss, a shorter height was observed in $9.1 \%{ }^{(20)}$. In the same study, there was no correlation between disease duration and nutritional status. In our study, lowered body height was also observed in four (4.2\%) patients, which is consistent with the literature. Additionally, there was also no correlation between disease duration and nutritional status in the present study $(P>0.05)$.

In a previous study, the height of parenterally infected children was shorter than those infected through vertical pathways $^{(12)}$. In the present study, the height of HBV-infected children receiving interferon or lamivudine therapy was found to be greater than those without treatment. In the current study, in terms of height and weight, there was a significant difference between the parenterally infected and vertically infected children $(P<0.05)$. In contrast to the previous study ${ }^{(12)}$, greater height and weight were detected more often in the parenterally infected children in our study. In addition, in our study, regarding height and weight, there was no significantly difference between the children with and without treatment $(P>0.05)$ or in terms of disease duration $(P>0.05)$. In regard to transmission mode, there was also no significant difference between disease duration $(P>0.05)$, but disease duration was longer in vertically infected children. It is possible that if disease duration is longer in vertically infected children, nutritional status may be more affected ${ }^{(27)}$.

Children with significantly elevated ALT levels were associated with short stature in two studies ${ }^{(9,12)}$. In contrast, Kuloglu et al. reported that chronic hepatitis B had no effect on children's growth ${ }^{(19)}$. Because there were only $49 \mathrm{HBV}$ pediatric patients in the Kuloglu et al. study, the effect of this study is weak. Our findings are compatible with those of Kuloglu et al. in terms of height and weight, in that there was no significant difference between children with higher and lower levels of ALT $(P>0.05)$. There were $96 \mathrm{HBV}$ pediatric patients in the present study; therefore, the effect of our study is greater than the Kuloglu et al. study.

One study showed that viral load did not affect children's growth ${ }^{(7)}$. There was also no difference in children's growth in regard to viral load in the current study, which is consistent with the literature. Vegnente et al. reported on seven $(9.3 \%)$ children with mild malnutrition, and biochemical abnormalities associated with malnutrition were not detected in all patients with chronic $\mathrm{HBV}^{(27)}$. According to the same criteria used in Vegnente et al. study, the present study showed that one $(1.0 \%)$ patient was moderately malnourished and $10(10.4 \%)$ were mildly malnourished. In addition, there were no biochemical laboratory abnormalities associated with malnutrition in our study, which is compatible with the literature.

The malnutrition rate was reported to be $21 \%$ in another study conducted in Turkey ${ }^{(27)}$. That study found that the factors affecting nutritional status were low educational levels of mothers and fathers, living in rural areas, and poor sanitation and hygiene. In addition, social factors affecting nutritional status are the number of children in the home, birth spacing, and where the mother works ${ }^{(26)}$. In our study, based on BMI centiles, five $(5.2 \%)$ patients were underweight, seven $(7.3 \%)$ were overweight, and seven $(7.3 \%)$ were obese. Consistent with the literature, both the socioeconomic status and educational level of parents were low in the majority of our cases; this may contribute to the moderate rate of malnutrition.

The age of diagnosis was later in children with malnutrition and the follow-up period was shorter in a previous study ${ }^{(27)}$. If there is a longer duration of chronic liver disease, nutritional status may be affected more; however, there was no difference in terms of nutritional status at different stages of liver disease in that study. If a patient is diagnosed early and is followed long-term, his or her nutritional status is 
monitored more carefully and nutritional support is given as needed ${ }^{(27)}$. In agreement with this, in our study, the age at diagnosis was older and the follow-up period was shorter in children with malnutrition, but there was no statistically significant difference between them $(P>0.05)$. Many parents of children with chronic HBV infection restrict oil in the diet. We have a chance to correct these mistakes at the time of admission, but because the current study is retrospective, we had no chance to change eating habits.

In the Vegnente et al. study, inadequate caloric intake as well as the degree of liver damage was identified in malnourished patients with chronic $\mathrm{HBV}^{(27)}$. In terms of liver damage, there was no significant difference in children who were or were not malnourished in our study $(P>0.05)$. Unfortunately, because the present study was retrospective, daily dietary intake could not be evaluated.

All findings except for AST levels were similar in patients with and without malnutrition in the Soylu et al. study ${ }^{(2)}$; however, AST is not specific to the liver, and other pathologies also raise AST levels. In addition, the prevalence of malnutrition was not different in children with normal or higher levels of AST in that study. Our findings are consistent with the Soylu et al. study.

It has been reported that there was no difference in the nutritional status between patients who did or did not receive treatment or whether patients responded to treatment or $\operatorname{not}^{(2,27)}$. These data suggest that chronic HBV infection has no effect on nutritional status ${ }^{(2,27)}$. Further, there was also no difference in the nutritional status between patients who did or did not receive treatment in our study, which is compatible with the literature.

The worldwide prevalence of childhood obesity has increased significantly in the past 30 years ${ }^{(14)}$, which also results in an increase of obesity-related comorbid disease. Childhood obesity affects almost every organ system negatively and often causes serious consequences, including hypertension, dyslipidemia, insulin resistance, fatty liver disease, and psychosocial complications. It may also cause a significant increase in health care expenditures ${ }^{(14)}$. In a multicenter study conducted in Europe, the combined prevalence of overweight/obesity ranged from more than $40 \%$ in southern Europe to less than $10 \%$ in northern Europe ${ }^{(1)}$. That study reported that the highest prevalence of obesity was in groups with a low income and/or lower education level. Based on body mass index centiles in the present study, the combined prevalence of overweight/obesity is $14.6 \%$. Consistent with a previous study ${ }^{(1)}$, risk factors for obesity in children were related to low socioeconomic status and low parental income in the current study.

To our knowledge, there were only two studies in adults that described the relationship between obesity and chronic HBV infection ${ }^{(7,8)}$. Those studies reported that the hepatitis B viral load was inversely associated with obesity. In contrast, the hepatitis B viral load was higher in eight (57.1\%) patients in the obese groups, but there was no significant difference between the obese and non-obese groups $(P>0.05)$. Because this study had a smaller number of patients, the effect of the present study is low, and further study is needed that includes a larger group of children to assess this relation.

The findings of this study suggest that chronic HBV infection has no effect on nutritional status. The detected underweight in five (5.2\%) patients and overweight/obesity in $14(14.63 \%)$ may be attributed to low socioeconomic status and low educational levels of parents.

As a result of the findings in the present study, moderate rates of malnutrition (including obesity) were also found in chronic HBV infection as in all chronic infections; additionally, the nutritional status of all healthy and sick children should be assessed early. In addition, timely interventions should be initiated because of malnutrition in developing countries such as ours. Additionally, preventing childhood obesity and diagnosing overweight/obese children at an early stage are important to starting treatment early and maintaining a healthy weight. The options of pharmacotherapy are very limited in pediatric obesity; therefore, a comprehensive management program including appropriate nutrition, exercise, and behavior modification should be established.

\section{ACKNOWLEDGEMENTS}

We thank to Doc. Dr. Ali Ibrahim Hatemi (MD, Division of Gastroenterology, Department of Internal Medicine, Cerrahpasa Faculty of Medicine, Istanbul University) for their assistance in statistical analysis. 
Şahin Y. Prevalência da desnutrição em crianças com infecção por hepatite B crônica. Arq Gastroenterol. 2016,53(2): 89-93.

RESUMO - Contexto - Há limitados estudos investigando o impacto da infecção crônica pelo vírus da hepatite B no crescimento das crianças. Objetivo - O objetivo deste estudo foi investigar a prevalência de desnutrição em crianças com infecção crônica da hepatite B. Métodos - O estado nutricional dos pacientes foi avaliado retrospectivamente em ambulatório de gastroenterologia clínica pediátrica, entre fevereiro e novembro de 2014. Durante o estudo, parâmetros bioquímicos do laboratório, duração da doença, classificação de biópsias hepáticas e medicação foram avaliadas. Além disso, o índice de massa corporal e suas porcentagens foram calculados. Resultados - Dos 96 pacientes, 68 eram do sexo masculino e 28 eram do sexo feminino e idade média era $144.7 \pm 43.9$ e de $146.1 \pm 47.3$ meses, respectivamente. De acordo com as porcentagens de índice de massa corporal, cinco $(5,2 \%)$ pacientes estavam abaixo do peso, sete (7,3\%) pacientes estavam com sobrepeso, e sete (7.3\%) estavam obesos. Conclusão - Taxas moderadas de desnutrição (incluindo obesidade) foram encontradas em infecção crônica da hepatite B. Informação sobre o estado nutricional das crianças infectadas deve ser colhida inicialmente para que intervenções oportunas sejam tomadas.

DESCRITORES - Transtornos da nutrição infantil. Hepatite B crônica. Estado nutricional.

\section{REFERENCES}

1. Ahrens W, Pigeot I, Pohlabeln H, De Henauw S, Lissner L, Molnar D, et al Prevalence of overweight and obesity in European children below the age of 10 . Int J Obes (Lond). 2014;38:S99-107.

2. Bekem Soylu O, Targan S, Diniz G, Ortac R. Nutritional status of children with chronic hepatitis B in a population with low socioeconomic status. Eur J Gastroenterol Hepatol. 2009;21:1252-5.

3. Bhutta ZA. Effect of infections and environmental factors on growth and nutritional status in developing countries. J Pediatr Gastroenterol Nutr. 2006;43:S13-21.

4. Cao J, Peng L, Li R, Chen Y, Li X, Mo B, et al. Nutritional risk screening and its clinical significance in hospitalized children. Clin Nutr. 2014;33:432-6.

5. Chang MH. Hepatitis B: long-term outcome and benefits from mass vaccination in children. Acta Gastroenterol Belg. 1998;61:210-3.

6. Chen HL, Lin LH, Hu FC, Lee JT, Lin WT, Yang YJ, et al. Effects of maternal screening and universal immunization to prevent mother-to-infant transmission of HBV. Gastroenterology. 2012;142:773-81.

7. Chiang $\mathrm{CH}$, Huang KC. Association between metabolic factors and chronic hepatitis B virus infection. World J Gastroenterol. 2014;20:7213-6.

8. Chiang CH, Yang HI, Jen CL, Lu SN, Wang LY, You SL, et al. REVEAL-HBV Study Group. Association between obesity, hypertriglyceridemia and low hepatitis B viral load. Int J Obes. 2013;37:410-5.

9. Comanor L, Minor J, Conjeevaram HS, Robert EA, Alvarez F, Bern EM, et al. Impact of chronic hepatitis B and interferon-alpha therapy on growth of children. $J$ Viral Hepat. 2001;8:139-47.

10. Davison S. Chronic hepatitis. In: Kelly DA, editor. Diseases of the liver and biliary system in children. 2nd ed. Massachusetts: PA Blackwell; 2004. p. 127-61.

11. De Onis M, Onyango AW, Borghi E, Siyam A, Nishida C, Siekmann J: Development of a WHO growth reference for school-aged children and adolescents. Bull World Health Organ 2007, 85:660-7.

12. Gerner P, Hörning A, Kathemann S, Willuweit K, Wirth S. Growth abnormalities in children with chronic hepatitis B or C. Adv Virol. 2012;670316, 5 pages.

13. Goldstein ST, Zhou F, Hadler SC, Bell BP, Mast EE, Margolis Hs. A mathematica model to estimate global hepatitis B disease burden and vaccination impact. Int J Epidemiol. 2005;34:1329-39.

14. Güngör NK. Overweight and obesity in children and adolescents. J Clin Res Pediatr Endocrinol. 2014;6:129-43.
15. Iorio R, Giannattasio A, Cirillo FD, Cirillo F, Alessandro L, and Vegnente A. Long-term outcome in children with chronic hepatitis B: a 24-year observation period. Clin Infect Dis. 2007;45:943-9.

16. Kanra G, Tezcan S, Badur S, Turkish National Study Team. Hepatitis B and measles seroprevalence among Turkish children. Turk J Pediatr. 2005;47:105-10.

17. Kidd-Ljunggren K, Holmberg A, Bläckberg J, Lindqvist B. High levels of hepatitis B virus DNA in body fluids from chronic carriers. J Hosp Infect. 2006;64:352-7.

18. Kruizenga HM, Tulder MWV, Seidell JC, Thijs A, Ader HJ, Van Bokhorst-de van der Schueren MA. Effectiveness and cost-effectiveness of early screening and treatment of malnourished patients. Am J Clin Nutr. 2005;82:1082-9.

19. Kuloğlu Z, Kansu A, Demirçeken F, Arici ZS, Berberoğlu M, Ocal G, et al. The influence of interferon- $\alpha$ and combination interferon- $\alpha$ and lamivudine therapy on height and weight in children with chronic hepatitis B infection. $J$ Pediatr Endocrinol Metab. 2007;20:615-20.

20. Kups J, Wozniakowska-Gesicka T, Wisniewska-Ligier M, Kubacki J. Evaluation of the somatic development in children with chronic virus hepatitis. Pol Merkur Lekarski. 2005;18:637-41.

21. Malina RM, Bouchard C, Bar-Or O. Growth, Maturation, And Physical Activity 2. ed. Champaign, IL: Human Kinetics; 2004.

22. Pelletier DL, Frongillo EA Jr, Schrroeder DG, Habicht JP. The effects of malnutrition on child mortality in developing countries. Bull World Health Organ. 1995;73:443-8.

23. Shepherd RW, Ramm GA. Fibrogenesis and cirrhosis. In: Walker WA, Goulet O, Kleinman RE, Sherman PM, Schneider BL, Sanderson Ir, editors. Pediatric gastrointestinal disease: pathophysiology, diagnosis, management. 4th ed. Ontario: BC Decker Inc; 2004. p. 80-8.

24. Sokol RJ, Stall C. Anthropometric evaluation of children with chronic liver disease. Am J Clin Nutr. 1990;52:203-8.

25. Tanaka J. Hepatitis B epidemiology in Latin America. Vaccine. 2000;18:S17-S19.

26. Tuncbilek E, Unalan T, Coskun T. Indicators of nutritional status in Turkish preschool children: results of Turkish Demographic and Health Survey 1993. J Trop Pediatr. 1996;42:78-84.

27. Vegnente A, Guida S, Di Costanzo C. Nutritional status and growth in children with chronic hepatitis B. J Pediatr Gastroenterol Nutr. 1992;14:123-7.

28. World Health Organization. Hepatitis B vaccines. Weekly Epidemiological Record. 2009;84:405-20. 